\title{
Corticosteroid Effect on Granulopoiesis in Mice
}

\section{after Cyclophosphamide}

\author{
Robert A. Joyce and Paul A. Chervenick \\ From the Department of Medicine, University of Pittsburgh School of Medicine, Pittsburgh, \\ Pennsylvania 15261
}

\begin{abstract}
A B S T RACT Corticosteroids cause an enhanced return of granulopoiesis as measured by in vitro growth of granulocytic progenitor cells (CFU-C) in mice treated with cyclophosphamide. After methylprednisolone and cyclophosphamide, a greater than threefold increase in marrow CFU-C was measured on day 4 compared to mice given cyclophosphamide alone $(29,700 \pm 200$ vs. $8,400 \pm 700 /$ humerus $)$. The accelerated return of marrow CFU-C was observed with cyclophosphamide in doses of 200 and $450 \mathrm{mg} / \mathrm{kg}$ and methylprednisolone, $2-20 \mathrm{mg} / \mathrm{kg}$, with no significant differences using $>5 \mathrm{mg} / \mathrm{kg}$, and was detected when dexamethasone was used in place of methylprednisolone. This effect was accompanied by similarly enhanced splenic granulopoiesis as measured by CFU-C concentration. Levels of colony stimulating activity did not differ in mice given methylprednisolone and cyclophosphamide or cyclophosphamide alone. Corticosteroids appear to enhance the return of CFU-C by altering the proliferative state of granulocytic progenitor cells. CFU-C survival to in vitro ${ }^{3} \mathrm{HTdR}$ suicide increased from $72 \pm 4 \%$ on day 1 after cyclophosphamide to $90 \pm 6 \%$ in animals given both cyclophosphamide and methylprednisolone. Increased survival after ${ }^{3} \mathrm{HTdR}$ suicide was also observed when methylprednisolone alone was given. After treatment with cyclophosphamide and methylprednisolone, blood neutrophils increased more rapidly and improved survival to infection with Candida albicans was observed. These studies demonstrate that corticosteroids have a beneficial effect on marrow regeneration after myelotoxic chemotherapy with cyclophosphamide and suggest that they act by altering cell cycle characteristics of granulocyte progenitor cells.
\end{abstract}

This work was presented in part at the American Federation of Clinical Research Meeting, May 1976, Atlantic City, N. J., and published in abstract form Clin. Res. 24: 377. (Abstr.).

Received for publication 16 December 1976 and in revised form 11 March 1977.

\section{INTRODUCTION}

Marrow toxicity represents a major limitation to treatment of malignant disorders. Major efforts continue to be directed toward development of agents capable of improved destruction of malignant cells; however, studies designed to modify toxicity to normal marrow progenitor cells have been limited (1-4).

The technique of in vitro growth of colonies of granulocytes and mononuclear cells in semisolid media has been used to characterize the compartment of cells presumed to be committed stem cells (CFU-C) ${ }^{1}$ in the marrow and blood $(5,6)$. Recent reports have indicated increased granulopoietic recovery with this technique in mice made neutropenic by cytotoxic drugs when given androgenic steroids (7). Adrenal cortical steroids are frequently used in combination with myelotoxic chemotherapy for treatment of malignancy. However, their effect on granulocyte kinetics, beyond causing release of cells from the marrow (8) and impaired migration of cells to exudates (9), has not been investigated in regenerating marrow. The effect of corticosteroids on granulopoietic recovery in mice after myelotoxic treatment with cyclophosphamide forms the basis of this report.

\section{METHODS}

$\left(\mathrm{C}_{57} \mathrm{~B}_{1}\right.$ female and DBA male) $\mathrm{F}_{1}$ female mice bred in our laboratory from stock purchased from The Jackson Laboratory, Bar Harbor, Me., were used in all experiments. Animals were between 9 and 15 wk of age.

Cyclophosphamide (Mead Johnson Laboratories, Evansville, Ind.), methylprednisolone (The Upjohn Company, Kalamazoo, Mich.), and dexamethasone (Merck Sharp \& Dohme, West Point, Pa.) were diluted in normal saline for injection. Control mice were saline injected. All drugs were given intraperitoneally in equivalent volumes.

\footnotetext{
${ }^{1}$ Abbreviations used in this paper: ${ }^{3} \mathrm{HTdR}$, tritiated thymidine; CFU-C, in vitro colony-forming cells; CSA, colony stimulating activity.
} 
Quantitative marrow counts were made from cell suspensions obtained by gently flushing the isolated mouse humerus with tissue culture medium, CMRL 1066, as described previously (10). Peripheral blood was obtained by orbital sinus puncture. Cell concentrations were measured with an electronic particle counter (Coulter Counter, Model B, Coulter Electronics Inc., Hialeah, Fla.) and from 200 cell differential counts of Wright's stained blood smears and 500 cell differential counts of cytocentrifuged marrow specimens. Spleen cell suspensions were obtained by gently flushing whole mouse spleens with culture media.

The concentrations of CFU-C from mouse marrow and spleen were determined by measuring colony formation in the soft gel system as described by Pluznik and Sachs (11) and by Bradley and Metcalf (12). Methylcellulose (Dow Corning Corp., Midland, Mich.) was used in place of agar (13). Cells were suspended in $1.8 \%$ methylcellulose containing culture medium CMRL 1066, 15\% horse serum, and 10\% L-cell conditioned medium. The combined mixture was then plated in triplicate in $1-\mathrm{ml}$ volumes in culture dishes $35 \times 10 \mathrm{~mm}$, and incubated at $37^{\circ} \mathrm{C}$ in $7.5 \% \mathrm{CO}_{2}$ for 7 days. Colonies containing more than 50 cells were counted with an inverted microscope.

Cell cycle characteristics of mouse CFU-C were measured by determining the degree to which colony forming capacity of the cultured cells was lost after tritiated thymidine $\left({ }^{3} \mathrm{HTdR}\right)$ suicide as described by Iscove et al. (14). On days 1 through 4 after treatment, marrow cells from mice given cyclophosphamide, cyclophosphamide and methylprednisolone, or methylprednisolone alone and marrow cells from salineinjected controls were suspended in ice-cold McCoys 5A culture media. Each marrow cell suspension was divided into three aliquots of $0.4 \mathrm{ml}$ containing $6-7 \times 10^{6}$ nucleated cells. ${ }^{3} \mathrm{HTdR}$ (thymidine [methyl- ${ }^{3} \mathrm{H}$ ], $20 \mathrm{Ci} / \mathrm{mmol}$, New England Nuclear Corporation, Boston, Mass.), $10 \mu \mathrm{Ci}$ in $0.4 \mathrm{ml}$ McCoys 5A media, was added to one aliquot of each marrow suspension. The remaining two aliquots were used as controls to which ${ }^{3} \mathrm{HTdR}, 10 \mu \mathrm{Ci}$, and McCoys $5 \mathrm{~A}$ media, $12 \mathrm{ml}$, containing unlabeled thymidine, $100 \mu \mathrm{g} / \mathrm{ml}$, and $10 \%$ fetal calf serum, or tissue culture media alone were added. After a 20-min incubation with gentle agitation in a $37^{\circ} \mathrm{C}$ water bath, uptake of ${ }^{3} \mathrm{HTdR}$ was stopped by the addition of $12 \mathrm{ml}$ of the ice-cold McCoys 5A media containing unlabeled thymidine and fetal calf serum. The cells were then centrifuged at $200 \mathrm{~g}$ for $12 \mathrm{~min}$ and washed twice. Final cell concentration was measured with a hemocytometer, and a Coulter counter check of these counts was made with the aliquot not exposed to ${ }^{3} \mathrm{HTdR}$. The cells were then assayed for colony formation as described previously. After 7 days incubation, the reduction in colony number from ${ }^{3} \mathrm{HTdR}$-treated cells was used as a measure of $\mathrm{CFU}-\mathrm{C}$ proliferative activity.

\section{RESULTS}

Mice were given cyclophosphamide in doses of 200$450 \mathrm{mg} / \mathrm{kg}$ with or without methylprednisolone, $5 \mathrm{mg} /$ $\mathrm{kg}$. There was no significant difference in quantitative marrow counts during the subsequent 8 days between mice given cyclophosphamide alone or with methylprednisolone. Marrow counts reached a nadir 3 days after treatment and increased to control levels by day 7. However, a difference was observed in marrow CFU-C after treatment with cyclophosphamide and methylprednisolone compared with treatment with cyclophosphamide alone (Fig. 1). In mice given cyclo-

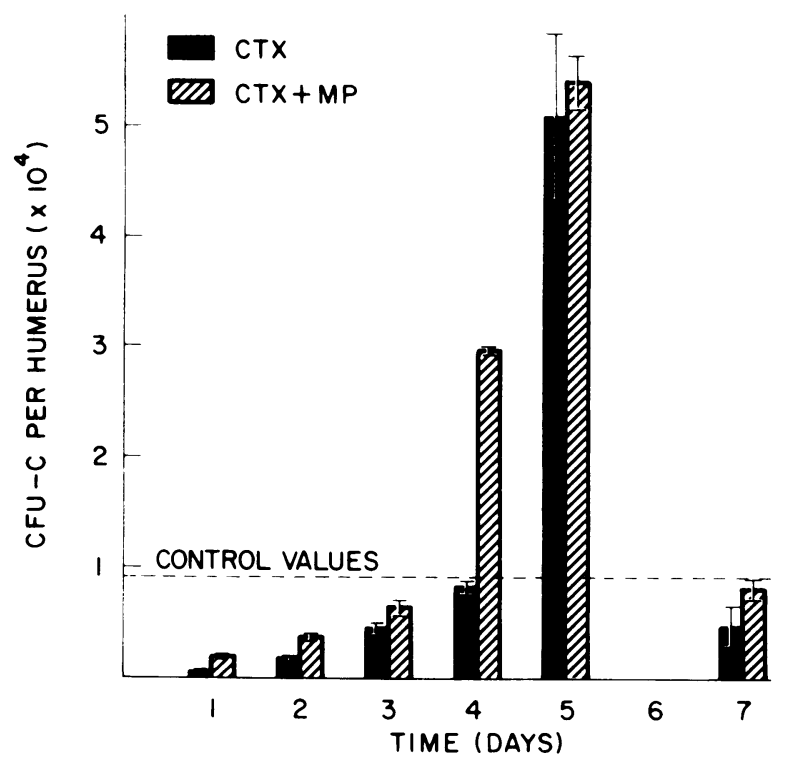

Figure 1 Marrow CFU-C after cyclophosphamide (CTX), $200 \mathrm{mg} / \mathrm{kg}$, and cyclophosphamide and methylprednisolone (MP), $5 \mathrm{mg} / \mathrm{kg}$. Values represent the number of CFU-C per humerus expressed as the mean $\pm S E$ of marrow samples from six to eight mice in two separate experiments, each plated in triplicate. MP was given $3 \mathrm{~h}$ before CTX.

phosphamide alone, $200 \mathrm{mg} / \mathrm{kg}$, marrow CFU-C content was decreased by day 1 to $400 \pm 70$ /humerus. Thereafter CFU-C content increased to normal levels of $8,400 \pm 700$ on day 4 , reached peak values on day 5 $(51,000 \pm 7,500)$, and then declined. In animals given methylprednisolone, $5 \mathrm{mg} / \mathrm{kg}, 3 \mathrm{~h}$ before cyclophosphamide, a decrease to $1,900 \pm 100 \mathrm{CFU}-\mathrm{C}$ occurred on day 1. However, by day 4 marrow CFU-C content increased to a level more than threefold greater than in mice given cyclophosphamide alone $(29,700 \pm 200$ /humerus vs. 8,400$)$. Peak values also occurred on day $5(54,400$ $\pm 2,500)$ followed by a decline. A similar effect on recovery of marrow CFU-C was observed in mice given methylprednisolone when maximally tolerated doses of cyclophosphamide, $450 \mathrm{mg} / \mathrm{kg}$, were used compared with mice given this dose of cyclophosphamide alone. On day 1, CFU-C decreased to $20 \pm 4$ /humerus after cyclophosphamide, $450 \mathrm{mg} / \mathrm{kg}$, and to $35 \pm 3$ in mice given cyclophosphamide and methylprednisolone. Marrow CFU-C then increased in both groups. On day 4, mice treated with methylprednisolone and cyclophosphamide had more than twice the number of CFU-C per humerus $(16,200 \pm 500)$ than mice given cyclophosphamide alone $(6,800 \pm 500)$. Again there was no difference in maximum CFU-C concentration reached on day $5(21,300 \pm 2,600$ and $26,000 \pm 3,900$, respectively).

The effect of methylprednisolone alone on marrow CFU-C is shown in Table I. On day 1 after treatment, the number of marrow CFU-C was significantly de- 
TABLE I

Marrow CFU-C after Methylprednisolone (MP)

\begin{tabular}{|c|c|c|}
\hline \multirow[b]{2}{*}{ Dose of MP } & \multicolumn{2}{|c|}{ CFU-C/Humerus* } \\
\hline & Day 1 & Day 4 \\
\hline $\mathrm{mg} / \mathrm{kg}$ & \multicolumn{2}{|c|}{$\%$ control } \\
\hline 20 & $77 \pm 2.9$ & $106 \pm 4.0$ \\
\hline 5 & $85 \pm 4.3$ & $108 \pm 13.0$ \\
\hline 2 & $99 \pm 15.2$ & $106 \pm 8.1$ \\
\hline
\end{tabular}

Controls contained 6,700 $\pm 400 \mathrm{CFU}-\mathrm{C} /$ humerus.

* Data represent mean $\pm \mathrm{SE}$ of pooled marrow samples from six mice in two separate experiments plated in triplicate and expressed as percent of untreated controls.

creased $(P<0.005)$ in mice given methylprednisolone in doses of 5 or $20 \mathrm{mg} / \mathrm{kg}$ with no difference noted after a dose of $2 \mathrm{mg} / \mathrm{kg}$. On day 4 , however, there was no difference in CFU-C concentration in any of the methylprednisolone-treated groups compared to control values. The effect of adding methylprednisolone directly to culture plates is seen in Table II. In a concentration of $0.1 \mu \mathrm{g}$ or less, no effect on CFU-C was observed. However, the addition of methylprednisolone in concentrations of 1,5 , or $10 \mu \mathrm{g}$ resulted in inhibition of CFU-C by 11,17 , and $24 \%$, respectively.

The accelerated return of marrow CFU-C in cyclophosphamide-treated mice receiving methylprednisolone was observed with methylprednisolone given in doses of $2-20 \mathrm{mg} / \mathrm{kg} 3 \mathrm{~h}$ before cyclophosphamide. Marrow CFU-C content was twofold greater on day 4 after methylprednisolone, $2 \mathrm{mg} / \mathrm{kg}$, and cyclophosphamide than after cyclophosphamide alone $(16,400 \pm 1,100$ vs. $8,300 \pm 700$ /humerus). A maximum increase of threeto fourfold was observed in mice given methylprednisolone, $5 \mathrm{mg} / \mathrm{kg}(29,000$ vs. 8,300$)$, with no further increase in marrow CFU-C content observed when methylprednisolone in doses $>5 \mathrm{mg} / \mathrm{kg}$ were used.

TABLE II

Inhibition of Colony Formation by Methylprednisolone (MP)

\begin{tabular}{cc}
\hline Dose of MP* & Colonies/105 marrow cells $₫$ \\
\hline$\mu g /$ culture & $105 \pm 3.2$ \\
10 & $115 \pm 2.8$ \\
5 & $123 \pm 7.1$ \\
1 & $137 \pm 8.1$ \\
0.1 & $142 \pm 7.0$ \\
0.01 & $138 \pm 4.8$ \\
\hline
\end{tabular}

* Constant volume of methylprednisolone $(0.05 \mathrm{ml})$ added to each culture $(1 \mathrm{ml})$ containing $0.05 \mathrm{ml} \mathrm{L}$-cell conditioned media to stimulate colony growth.

† Data from two separate experiments plated in triplicate and expressed as mean $\pm \mathrm{SE}$.
When dexamethasone, $1 \mathrm{mg} / \mathrm{kg}$, was used in place of methylprednisolone, a similar pattern of earlier recovery of marrow CFU-C was observed. Marrow CFU-C decreased to $1,500 \pm 100$ /humerus on day 1 after cyclophosphamide, $200 \mathrm{mg} / \mathrm{kg}$, and dexamethasone and increased to $31,500 \pm 5,300$ by day 4 with maximum CFU-C concentration reached on day 5 .

To determine the optimal time for steroid administration to be effective, administration of methylprednisolone was varied relative to the time of giving cyclophosphamide. These results are seen in Table III. Marrow CFU-C were similarly reduced during the first three days after treatment with cyclophosphamide regardless of the time of administration of methylprednisolone. However, the administration of methylprednisolone at 12 or $24 \mathrm{~h}$ before cyclophosphamide resulted in a significant increase in CFU-C content to 17,400 and 18,400 , respectively, on day 4 compared with controls not receiving methylprednisolone $(8,400)$. However, the effect of methylprednisolone was most marked when given $3 \mathrm{~h}$ before cyclophosphamide at which time an increase to $29,700 \pm 200$ was observed. Giving methylprednisolone simultaneously or $48 \mathrm{~h}$ before cyclophosphamide resulted in a slight but nonsignificant increase in CFU-C and no increase was observed when methylprednisolone was given 18 $h$ after cyclophosphamide.

To determine the effect of methylprednisolone on splenic granulopoiesis in mice given cyclophosphamide, spleen cells obtained from mice after treatment with cyclophosphamide with and without methylprednisolone were assayed for CFU-C content (Table IV). The pattern was similar to that observed in the marrow. There was no significant difference in CFU-C concentration in the spleen 1 day after treatment. However, by day 4 mice given methylprednisolone contained a nearly twofold greater concentration of

\section{TABLE III}

Effect of Time of Administration of Methylprednisolone (MP) on Marrow CFU-C in Animals Receiving Cyclophosphamide

\begin{tabular}{cc}
\hline Time of MP administration & CFU-C* \\
\hline$h$ & per humerus \\
-48 & $11,900 \pm 2,100$ \\
-24 & $18,400 \pm 1,600$ \\
-12 & $17,400 \pm 1,500$ \\
-3 & $29,700 \pm 200$ \\
0 & $12,100 \pm 1,400$ \\
+18 & $7,300 \pm 1,000$ \\
Controls (untreated) & $9,000 \pm 500$
\end{tabular}

* Values represent mean \pm SE of CFU-C measured on day 4 after administration of MP $(5 \mathrm{mg} / \mathrm{kg})$ before $(-)$ or after $(+)$ cyclophosphamide $(200 \mathrm{mg} / \mathrm{kg})$ and measured in untreated controls. 
TABLE IV

Splenic Granulopoiesis

\begin{tabular}{cccccc}
\hline & \multicolumn{2}{c}{ CFU-C/10s cells } & & \multicolumn{2}{c}{ Spleen weight } \\
\cline { 2 - 3 } \cline { 5 - 6 } Time & CTX $^{*}$ & CTX + MP & & CTX & CTX + MP \\
\hline days & & & & \multicolumn{2}{c}{$m g$} \\
1 & $12 \pm 1.5$ & $8 \pm 1.3$ & & $50 \pm 8.1$ & $50 \pm 2.1$ \\
4 & $18 \pm 1.2$ & $31 \pm 3.8$ & & $42 \pm 4.3$ & $37 \pm 4.7$ \\
5 & $126 \pm 11.0$ & $147 \pm 13.3$ & & $39 \pm 3.7$ & $53 \pm 5.1$ \\
7 & $181 \pm 15.6$ & $164 \pm 14.2$ & & $74 \pm 4.3$ & $114 \pm 16.3$ \\
9 & $104 \pm 8.5$ & $86 \pm 11.0$ & & $197 \pm 13.6$ & $212 \pm 17.9$ \\
11 & $62 \pm 1.3$ & $42 \pm 5.7$ & & $182 \pm 30.7$ & $171 \pm 15.9$ \\
15 & $23 \pm 1.4$ & $20 \pm 0.8$ & & $94 \pm 12.7$ & $108 \pm 2.1$ \\
Controls & \multicolumn{3}{c}{$3 \pm 0.6$} & & \multicolumn{3}{c}{$90 \pm 5.0$} \\
\cline { 6 - 7 }
\end{tabular}

Values represent mean $\pm \mathrm{SE}$ of CFU-C concentrations from pooled spleen cell suspensions and of spleen weights from six to eight mice in two separate experiments each plated in triplicate. Control values were obtained from 12 untreated mice.

* CTX, cyclophosphamide; MP, methylprednisolone.

CFU-C in their spleens compared with mice given only cyclophosphamide $\left(30.7 \pm 3.8\right.$ vs. $18.3 \pm 1.2 / 10^{5}$ cells, $P<0.01$ ). That significant splenic granulopoiesis occurs after cyclophosphamide is supported by both the sustained increases in CFU-C concentration in both groups of animals over control values and the increase in spleen weight on day 9 to more than double the control values.

To determine whether the accelerated return of CFU-C in cyclophosphamide-treated mice given methylprednisolone was the result of increased levels of colony stimulating activity (CSA), sera from mice given cyclophosphamide alone or cyclophosphamide with methylprednisolone were tested for CSA in cultures of normal mouse marrow cells (Table V). Sera from mice given either cyclophosphamide or cyclophosphamide plus methylprednisolone contained increased levels of CSA by day 2 after treatment with little difference between the two groups. Thereafter levels remained elevated through day 5 , returning to control values by day 7 .

The effect of corticosteroids on the cell cycle characteristics of CFU-C from mice given cyclophosphamide or cyclophosphamide and methylprednisolone was measured by determining the percent survival of CFU-C after in vitro exposure to ${ }^{3} \mathrm{HTdR}$ (Table VI). On day 1 in mice given cyclophosphamide and methylprednisolone, a significant increase in survival of CFU-C was observed after exposure to ${ }^{3} \mathrm{HTdR}(90 \pm 6 \%)$ compared with either controls or to mice given cyclophosphamide alone $(72 \pm 4 \%, P<0.025)$. This difference was less on day 2 , and by day 3 essentially no difference was observed. On day 4 , survival was somewhat less, $42 \pm 1 \%$ of CFU-C compared to $50 \pm 1 \%$ in the
TABLE V

Colony Stimulating Activity in Serum after Cyclophosphamide with and without Methylprednisolone

\begin{tabular}{crr}
\hline & \multicolumn{2}{c}{ Colonies $/ 10^{5}$ marrow cells } \\
\cline { 2 - 3 } Time & \multicolumn{1}{c}{$\mathrm{CTX}^{*}$} & \multicolumn{1}{c}{ CTX $+\mathrm{MP}$} \\
\hline days & & \\
1 & $6.2 \pm 1.7$ & $5.2 \pm 1.2$ \\
2 & $54.0 \pm 3.2$ & $66.3 \pm 1.8$ \\
3 & $60.5 \pm 3.4$ & $51.0 \pm 2.7$ \\
4 & $68.3 \pm 2.0$ & $59.3 \pm 1.2$ \\
5 & $44.6 \pm 5.5$ & $42.6 \pm 3.0$ \\
7 & $7.2 \pm 1.7$ & $4.3 \pm 1.3$ \\
Control & \multicolumn{2}{c}{$4.4 \pm 0.7$} \\
\end{tabular}

Values represent colonies $/ 10^{5}$ normal marrow cells stimulated by $0.1 \mathrm{ml}$ serum obtained from groups of 10 mice at intervals indicated after treatment and expressed as mean $\pm \mathrm{SE}$ of two experiments plated in triplicate. Blood was obtained from the inferior vena cava of mice under ether anesthesia.

* Abbreviations as in Table IV.

group given only cyclophosphamide. Enhanced survival after ${ }^{3} \mathrm{HTdR}$ suicide was also observed on days 1 and 2 in mice given methylprednisolone alone compared with untreated controls.

Although there was no difference in quantitative marrow counts between cyclophosphamide- or cyclophosphamide- and methylprednisolone-treated mice, a difference in blood neutrophil concentration was observed as shown in Fig. 2. During the first 4 days after treatment, neutrophil concentrations decreased in both groups. Thereafter, blood neutrophil concentrations increased more rapidly in mice given methylprednisolone and cyclophosphamide, reaching levels of $9,600 \pm 600$ and $11,700 \pm 1,900 / \mu l$ on days 7 and 8 compared with $6,800 \pm 700$ and $9,000 \pm 700 / \mu l$ in mice given only cyclophosphamide $(P<0.05)$. Neutrophil counts then declined toward control values in both groups by days 10 and 12 after treatment.

TABLE VI

Effect of Corticosteroids on Cell Cycle Characteristics of CFU-C

\begin{tabular}{lcccc}
\hline & \multicolumn{4}{c}{ Percent survival of CFU-C after ${ }^{3} \mathrm{HTdR}^{*}$} \\
\cline { 2 - 5 } Time & Control & CTX $₫$ & CTX + MP & MP \\
\hline Day 1 & $77 \pm 4$ & $72 \pm 4$ & $90 \pm 6$ & $91 \pm 2$ \\
Day 2 & $76 \pm 3$ & $51 \pm 3$ & $64 \pm 10$ & $85 \pm 4$ \\
Day 3 & $65 \pm 1$ & $59 \pm 5$ & $55 \pm 12$ & - \\
Day 4 & $72 \pm 2$ & $50 \pm 1$ & $42 \pm 1$ & $70 \pm 7$
\end{tabular}

* Percent survival of CFU-C from mouse marrow after 20 min incubation with ${ }^{3} \mathrm{HTdR}, 10 \mu \mathrm{Ci} / \mathrm{ml}$, expressed as mean $\pm \mathrm{SE}$. $\$$ Abbreviations as in Table IV. 


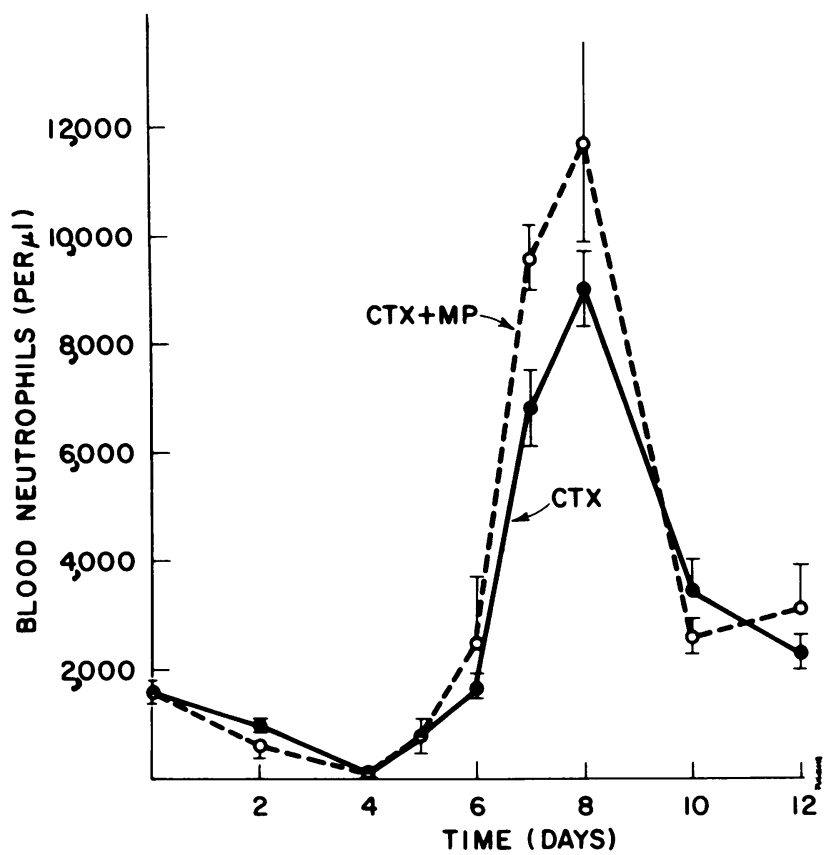

FIGURE 2 Blood neutrophil concentrations after cyclophosphamide (CTX), $200 \mathrm{mg} / \mathrm{kg}$, and cyclophosphamide and methylprednisolone (MP), $5 \mathrm{mg} / \mathrm{kg}$. Each value represents the mean $\pm \mathrm{SE}$ of six mice.

To determine if the enhanced recovery of granulopoiesis using methylprednisolone in combination with cyclophosphamide might have a beneficial effect in combating infection, the survival of mice infected with $C$. albicans was studied. Groups of 50 mice were given $10^{7} \mathrm{C}$. albicans intraperitoneally on the 2 nd day and after administration of cyclophosphamide or cyclophosphamide and methylprednisolone at a time when blood neutrophil concentrations were decreasing in both groups. As shown in Fig. 3, a significant improvement in survival was observed in mice given cyclophosphamide and methylprednisolone by day 4 of infection (62 vs. $36 \%$ survival). No additional deaths occurred after day 8 of infection. There were no deaths in untreated mice given C. albicans or in mice treated with methylprednisolone alone 2 days before $C$. infection. No difference in survival was noted when Candida was given at earlier time intervals after drug treatment.

\section{DISCUSSION}

These studies demonstrate that corticosteroids enhance granulopoietic recovery in mice treated with cyclophosphamide. The degree of enhanced recovery with methylprednisolone is dose dependent, present within a wide dose range of cyclophosphamide, and is dependent on the time of administration of corticosteroids relative to treatment with cyclophospha- mide. Although there was no difference in subsequent quantitative marrow counts in cyclophosphamidetreated mice with or without methylprednisolone, a threefold increase in marrow CFU-C was observed on day 4 in cyclophosphamide-treated mice given methylprednisolone compared with mice given cyclophosphamide alone. Similar differences were noted in splenic CFU-C concentrations. The enhanced return of marrow CFU-Cs was observed with methylprednisolone given at doses between 2 and $20 \mathrm{mg} / \mathrm{kg}$ and with cyclophosphamide to maximally tolerated doses of 450 $\mathrm{mg} / \mathrm{kg}$. Maximum enhancement ocurred when methylprednisolone was given $3 \mathrm{~h}$ before cyclophosphamide although increased levels of CFU-C were detected when methylprednisolone was given up to $24 \mathrm{~h}$ before cyclophosphamide. Enhanced marrow recovery was also observed when dexamethasone was used in place of methylprednisolone.

Previous studies have suggested that treatment with corticosteroids reduces marrow CFU-C content. Metcalf (15) reported that marrow CFU-C concentration decreased in normal mice given cortisone acetate alone in doses roughly equivalent to the high dose of methylprednisolone, $20 \mathrm{mg} / \mathrm{kg}$, used in this study. In the present study, a moderate reduction of marrow CFU-C content was noted on day 1 in normal mice given methylprednisolone, $5-20 \mathrm{mg} / \mathrm{kg}$. This reduction was transient, however, and not observed by day 4 after treatment. No reduction was noted when smaller doses of methylprednisolone, comparable to those used in combination chemotherapy in man (16), were used. The inhibition of colony formation by addition of methylprednisolone directly to marrow cell cultures has been noted previously (15). However, no inhibition was detected when methylprednisolone was added to cultures in concentrations $<5 \mu \mathrm{g} / \mathrm{ml}$.

A correlation of hematopoietic recovery to the proliferative state of marrow cells after cyclophosphamide

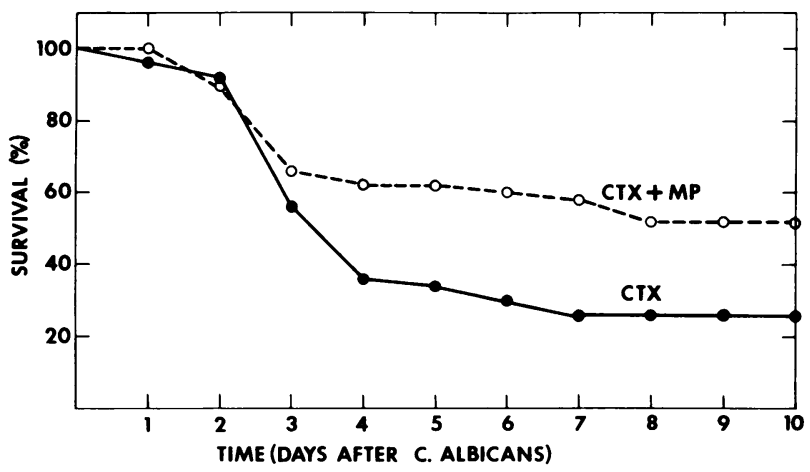

Figure 3 Survival after C. albicans. Values represent the percent survival after intraperitoneal injection of $10^{7} \mathrm{C}$. albicans on the 2 nd day after administration of cyclophosphamide (CTX), $200 \mathrm{mg} / \mathrm{kg}$, or cyclophosphamide and methylprednisolone (MP), $5 \mathrm{mg} / \mathrm{kg}$, to groups of 50 mice. 
treatment has been demonstrated in previous reports $(17,18)$. Corticosteroids appear to enhance the return of CFU-C after cyclophosphamide treatment of mice by altering the proliferative state of granulocytic progenitor cells. Treatment with methylprednisolone alone resulted in increased CFU-C survival to ${ }^{3} \mathrm{HTdR}$ suicide for 2 days after treatment. Similar changes in cell cycle were observed when methylprednisolone was given to cyclophosphamide-treated mice. The data suggest that a larger portion of precursor cells are removed from replicative cycle by corticosteroid treatment, allowing them to escape the cytotoxic effects of cyclophosphamide early after treatment. By day 4, survival of CFU-C after ${ }^{3}$ HTdR decreased in cyclophosphamide- and methylprednisolone-treated mice. This corresponded to the time of increased proliferation of CFU-C in those mice compared to mice given only cyclophosphamide.

The earlier return of CFU-C did not appear related to changes in serum CSA levels in cyclophosphamidetreated mice given methylprednisolone. In animals receiving cyclophosphamide alone or cyclophosphamide and methylprednisolone, serum CSA increased to similar levels by day 2 after treatment and corresponded to the onset of peripheral neutropenia. CSA levels remained elevated until day 7 when peripheral neutrophilia was observed. Craddock and co-workers (19) reported reduced colony formation in human subjects treated with high-dose methylprednisolone for renal allograph rejection and suggested that steroids cause a decrease in generation of CSA in vitro. Metcalf (20) has also suggested that colony number and size are influenced by changes in CSA release by the marrow cells in vitro. Although differences in colony number were observed in cyclophosphamide-treated mice when given methylprednisolone, no difference in estimated colony size were observed between the two groups.

It is possible that the enhanced granulopoiesis observed in methylprednisolone-treated mice may have been the result of altered metabolism of cyclophosphamide to its myelotoxic derivatives. Tredger et al. (21) have recently reported that whereas dexamethasone increases microsomal content and associated drug metabolizing enzyme activities in rat liver, no increase was observed with prednisolone. In the present study, similarly enhanced marrow CFU-C content was detected in cyclophosphamide-treated mice given either dexamethasone or methylprednisolone. Furthermore, the similarity of reduction of both quantitative marrow counts and blood neutrophil concentrations during the 3 days after treatment with cyclophosphamide with or without methylprednisolone, while not demonstrating similarity of drug metabolism, suggests that alteration of cyclophosphamide metabolism due to corticosteroids was probably not a major factor contributing to the earlier recovery of granulopoiesis. That methylprednisolone alone alters granulocyte progenitor cells is further supported by the changes in CFU-C cell cycle observed in mice given methylprednisolone without cyclophosphamide.

Previous studies have demonstrated that mortality after C. albicans infection in mice treated with cyclophosphamide is related to the severity and duration of leukopenia (22). In the present study, survival was greater when C.albicans was given to mice treated with cyclophosphamide and methylprednisolone than in mice treated with cyclophosphamide alone. This suggests that the enhanced granulopoiesis observed when methylprednisolone is given with cyclophosphamide is probably responsible for the improved ability to resolve subsequent infection. Even though the duration of neutropenia in uninfected animals treated with cyclophosphamide with or without methylprednisolone was similar, additional factors such as differences in neutrophil migration to areas of infection and host immune responses may also contribute to survival.

These studies indicate that corticosteroids enhance the return of CFU-C in cyclophosphamide-treated animals and suggest that corticosteroids act by altering cell cycle characteristics. The earlier return of marrow CFU-C is accompanied by a similar increase in spleen CFU-C, by a more rapid increase in blood neutrophils and by an improved tolerance to infection. These studies suggest that treatment with corticosteroids has a beneficial effect on normal marrow regeneration after myelotoxic chemotherapy with cyclophosphamide.

\section{ACKNOWLEDGMENTS}

We are thankful to M. J. Turner, R. P. Kim, and M. McDevitt for their excellent assistance with these studies.

This work was supported by grants (1 F 22 CA 00254-01 and CA 14278-03) from the U. S. Public Health Service and a grant (CH 21G) from the American Cancer Society.

\section{REFERENCES}

1. Smith, W. W., G. Brecher, S. Fred, and R. A. Budd. 1966. Effect of endotoxin on the kinetics of hemopoietic colony-forming cells in irradiated mice. Radiat. Res. 27: 710-717.

2. Brecher, G., W. W. Smith, S. Wilson, and S. Fred. 1967. Kinetics of colchicine-induced hemopoietic recovery in irradiated mice. Radiat. Res. 30: 600-610.

3. Boggs, D. R., J. C. Marsh, P. A. Chervenick, G. E. Cartwright, and M. M. Wintrobe. 1968. Factors influencing hematopoietic spleen colony formation in irradiated mice. VI. The different effects of foreign plasma, endotoxin, and bleeding on colony-forming cell kinetics. Radiat. Res. 35: 68-77.

4. Keizer, H. J., and L. M. van Putten. 1976. The radioprotective action on bone marrow CFU during immobilization of mice. Radiat. Res. 66: 326-336. 
5. Pike, B. L., and W. A. Robinson. 1970. Human bone marrow colony growth in agar-gel. J. Cell. Physiol. 76: 77-84.

6. Chervenick, P. A., and D. R. Boggs. 1971. In vitro growth of granulocytic and mononuclear cell colonies from blood of normal individuals. Blood. 37: 131-135.

7. Udupa, K. B., and K. R. Reissmann. 1974. Acceleration of granulopoietic recovery by androgenic steroids in mice made neutropenic by cytotoxic drugs. Cancer Res. 34: 2517-2520.

8. Mechanic, R. C., E. Frei, III, M. Landy, and W. W. Smith. 1962. Quantitative studies of human leukocytic and febrile response to single and repeated doses of purified bacterial endotoxin. J. Clin. Invest. 41: 162-172.

9. Bishop, C. R., J. W. Athens, D. R. Boggs, H. R. Warner, G. E. Cartwright, and M. M. Wintrobe. 1968. Leukokinetic studies. XIII. A non-steady state kinetic evaluation of the mechanism of cortisone-induced granulocytosis. J. Clin. Invest. 47: 249-260.

10. Chervenick, P. A., D. R. Boggs, D. R. Marsh, G. E. Cartwright, and M. M. Wintrobe. 1968. Quantitative studies of blood and bone marrow neutrophils in normal mice. Am. J. Physiol. 215: 353-360.

11. Pluznik, D. H., and L. Sachs. 1965. The cloning of normal "mast" cells in tissue culture. J. Cell. Comp. Physiol. 66: 319-324.

12. Bradley, T. R., and D. Metcalf. 1966. The growth of mouse bone marrow cells in vitro. Aust. J. Exp. Biol. Med. Sci. 44: 287-299.

13. Chervenick, P. A., and D. R. Boggs. 1970. Bone marrow colonies: stimulation in vitro by supernatant from incubated human blood cells. Science (Wash. D. C.). 169: 691-692.
14. Iscove, N. N., J. E. Till, and E. A. McCulloch. 1970. The proliferative states of mouse granulopoietic progenitor cells. Proc. Soc. Exp. Biol. Med. 134: 33-36.

15. Metcalf, D. 1969. Cortisone action on serum colonystimulating factor and bone marrow in vitro colony forming cells. Proc. Soc. Exp. Biol. Med. 132: 391-394.

16. Farhangi, M., and E. F. Osserman. 1973. The treatment of multiple myeloma. Semin. Hematol. 10: 149-161.

17. DeWys, W. D., A. Goldin, and N. Mantel. 1970. Hematopoietic recovery after large doses of cyclophosphamide: correlation of proliferative state with sensitivity. Cancer Res. 30: 1692-1697.

18. Rosenoff, S. H., F. Bostick, and R. C. Young. 1975. Recovery of normal hematopoietic tissue and tumor following chemotherapeutic injury from cyclophosphamide (CTX): comparative analysis of biochemical and clinical techniques. Blood. 45: 465-475.

19. Craddock, C. G., E. F. Hays, R. Forsen, N. Dabir-Vaziri, and D. Rodensky. 1974. Corticosteroids and granulopoiesis. Blood., 44: 951.

20. Metcalf, D. 1970. Studies on colony formation in vitro by mouse bone marrow cells. II. Action of colony stimulating factor. J. Cell. Physiol. 76: 89-99.

21. Tredger, J. M., J. Chakraborty, and D. V. Parke. 1976. Effect of natural and synthetic glucocorticoids on rat hepatic microsomal drug metabolism. J. Steroid Biochem. 7: 351-356.

22. Mukherji, A. K., and K. C. Basu Mallick. 1972. Disseminated candidosis in cyclophosphamide-induced leukopenic state: an experimental study. Indian J. Med. Res. 60: 1584-1591. 